Terbit online pada laman web jurnal: http://jurnal.iaii.or.id

\begin{tabular}{c} 
JURNAI, R SS'II \\
IAll \\
$\begin{array}{l}\text { (Rekayasa Sistem dan Teknologi Informasi) } \\
\text { Vol.5 No.5 (2021) } 1008-1015\end{array}$ \\
\hline
\end{tabular}

\title{
Pengembangan Aplikasi Asisten Pintar Pembuka Al Qur'an 30 Juz dengan Perintah Voice Command
}

\author{
Amarul Akbar ${ }^{1}$, Shofiyah $^{2}$, Nur Hayatin ${ }^{3}$, Ilyas Nuryasin ${ }^{4}$ \\ 1,2,3,4 Informatika, Teknik, Universitas Muhammadiyah Malang \\ 1 amarulakbar@webmail.umm.ac.id, ${ }^{2}$ shofiyahpeace@gmail.com, ${ }^{3}$ noorhayatin@gmail.com, ${ }^{4}$ ilyas@umm.ac.id
}

\begin{abstract}
Many developers of digital Qur'an applications today still use tap to scrolling to run applications, although the features are interesting. This makes it less effective and efficient in opening the Qur'an. As is the case during the taklim assembly, some da'i are very interactive with jama'ah, asking to open certain surahs and verses so that there are some who have difficulty in searching. Therefore, the need for the Qur'anic application with voice command command to facilitate users. This research is the development of the Qur'an application with voice recognition feature. Using the waterfall method in development, voice command with google speech API as a voice command of surah and verse calling in the Qur'an application 30 juz. Conducted 10 randomized experiments with calls in the form of play or open surahs and certain verses give a $90 \%$ accuracy result. Commands can be given when online or offline. Then the use of google speech API can be very useful for use in the development of other applications.
\end{abstract}

Keywords: voice command, speech to text, google API, waterfall, Al Qur'an.

\begin{abstract}
Abstrak
Banyak developer aplikasi Al-Qur'an digital saat ini masih menggunakan tap hingga scrolling untuk menjalankan aplikasi, meskipun fiturnya menarik. Hal itu menjadikan kurang efektif dan efisien dalam membuka Al-Qur'an. Seperti halnya saat majelis taklim, beberapa da'i sangat interaktif dengan jama'ah, meminta untuk membuka surah dan ayat tertentu sehingga ada beberapa yang kesulitan dalam mencari. Oleh karena itu perlunya aplikasi Al Qur'an dengan perintah voice command untuk memudahkan pengguna. Penelitian ini merupakan pengembangan aplikasi Al Qur'an dengan fitur voice recognition. Menggunakan metode waterfall dalam pengembangan, voice command dengan google speech API sebagai perintah suara pemanggilan surah dan ayat dalam aplikasi Al Qur'an 30 juz. Dilakukan 10 kali percobaan secara acak dengan pemanggilan berupa putar atau buka surah dan ayat tertentu memberikan hasil akurasi 90\%. Perintah bisa diberikan ketika dalam keadaan online maupun offline. Maka penggunaan google speech API dapat sangat berguna untuk digunakan dalam pengembangan aplikasi lainnya.
\end{abstract}

Kata kunci: voice command, speech to text, google API, waterfall, Al Qur'an.

\section{Pendahuluan}

Al Qur'an sebagaimana yang kita ketahui bersama merupakan kitab suci umat Islam yang diturunkan 1400 tahun lalu kepada Nabi Muhammad shallallahu 'alaihi wasssalam melalui jalur wahyu. Di mana Al Qur'an adalah kalam atau perkataan Allah sang pencipta yang diturunkan kepada manusia untuk menjadi pedoman hidup. Menerapkan Al Qu'ran pada kehidupan adalah kewajiban semua muslim, termasuk membaca dan Data dari Dewan Penasihat Nusantara Mengaji, jumlah menghafalnya. Maka tidak heran jutaan orang umat hafidz (penghafal qur'an) di Indonesia masih belum muslim, baik yang mengerti atau pun tidak terkait ideal karena KEMENAG mengatakan dari 250 juta artinya dan yang bisa atau pun tidak bisa menulis penduduk, baru ada 30 ribu penghafal. Selain itu jumlah hurufnya oleh orang tua, remaja sampai anak-anak penyandang disabilitas di Indonesia ada sekitar 5,6 juta, 
dan 2,2 juta diantaranya merupakan penyandang tunanetra (KEMENKES 2014). Sedangkan teknologi yang memudahkan penyandang disabilitas termasuk
tunanetra dalam menghafal Al- Qur'an sangat terbatas[3].

Berdasarkan observasi yang dilakukan ada banyak ditemukan aplikasi Al Qur'an berbasis android yang telah dikembangkan oleh para developer baik yang lengkap dengan pemutar lantunan, tajwid, hafalan, bacaan bahkan posting tulisan seperti Al Qur'an Indonesia, UMMA dan lainnya. Tetapi sayangnya masih menggunakan tap untuk memutar atau memanggil surah dam ayat. Adapun pada penelurusan HKI juga masih belum ada ditemukan aplikasi dengan basis voice command. Padahal banyak orang yang mendengarkan lantunan ayat suci Al Qur'an tersebut ketika sedang dalam perjalanan, berlari atau aktivitas lainnya yang membuat mereka menyimpan smartphone di dalam saku. Sehingga agak menyulitkan jika harus membuka smartphone kembali untuk memilih atau memutar yang lain[4].

Maka perlunya aplikasi Al Qur'an audio menggunakan voice command berbasis android dengan dilengkapi sistem speech recognition atau speech to text. Speech recognition atau speech to text sudah banyak digunakan untuk mempermudah jika seseorang tidak ingin menginput atau menulis teks pada aplikasi, yang dilakukan hanya memberintah dengan suara untuk menjalankan. Banyak penelitian di seluruh dunia telah melakukan percobaan metode dan algoritma yang kuat serta tinggi untuk mendapati akurasi dalam pengenalan ucapan. Seperti halnya speech recognition dengan artifical neural network menggunakan metode speech recognition Mel Frequency Cepstral Coefficient (MFCC) dan Dynamic Time Warping (DTW), voice
recognition mengounakan Hidden Markov model yang recognition menggunakan Hidden Markov model yang menghasilkan akurasi hingga 88,67\%[5].

Google menawarkan sebuah fitur pada Android untuk membuat suara sebagai metode input, sebagaimana penelurusan melalui suara dengan menggunakan google speech Aplication Programming Interface (API). Sistem ini mampu mengenali berbagai macam suara manusia. Google speech API adalah salah satu layanan machine learning dan termasuk kategori Artificial Intellegent[6]. Berapa penelitian yang dilakukan dengan menggunakan Google speech API diantaranya oleh Hayatun Nufus tentang "Rancang Bangun Aplikasi Al Quran Digital Untuk penyandang Disabilitas Tangan Berbasis Command Voice Pada Perangkat Andorid" dengan percobaan pemanggilan 38 surah dengan nomor mempunyai tingkat akurasi $100 \%$, sedangkan dengan nama surah adalah 98\%[5]. Dan "prototype aplikasi pencarian informasi ayat berdasarkan suraa bacaannya berbasis android" oleh Fakhrul Islam dengan akurasi $90 \%$ [7].
Aplikasi yang diusulkan adalah berupa "Aplikasi Asisten Pintar Pembuka Al Qur'an 30 Juz dengan Perintah Voice Command" berbasis android. Sistem operasi android yang bersifat opensource dan merupakan $S O$ perangkat mobile yang paling banyak penggunanya di seluruh dunia termasuk Indonesia, menjadikan hal tersebut menjadi salah satu alasan pengembangan. Pengembangan aplikasi Al-Qur'an ini sudah dalam bentuk aplikasi android versi 1.0. Sedangkan untuk penelitian sendiri berfokus pada penerapan speech recognition dengan Google API sebagai sebuah fitur pencarian dengan masukkan berupa perintah untuk memutar atau membuka surah dan ayat tertentu yang diharapkan dapat menjadi acuan pengembangan aplikasi Al-Qur'an kedepannya. Sehingga dapat membantu dan memuaskan banyak kalangan orang untuk membaca dan menghafal AlQur'an dengan mudah dan efisien waktu.

\section{Metode Penelitian}

Penelitian ini menggunakan metode waterfall sebagai acuan tahap pengerjaanya[8]. Dimulai dari suatu permasalahan yang telah dijelaskan sebelumnya, maka tahap awal yang dilakukakan adalah analisa sistem. Tahap ini sangat penting karena disini akan diuraikan kebutuhan-kebutuhan apa saja yang diperlukan dalam penelitian ini yang mempengaruhi keberhasilan sistem nantinya. Dari kebutuhan fungsional terkait fitur-fitur dan non fungsional sebagai perangkat untuk merealisasikannya.

Tahapan berikutnya adalah perancangan sistem. Perancangan yang dibuat berupa Unified Model Language (UML), seperti flowchart, use case diagram, database dan perancangan interface agar tahap implementasi mudah untuk dikerjakan[9].

Terakhir adalah tahap implementasi dan pengujian. Tahap ini merupakan penerapan dari rangkaian uraian tahap sebelumnya. Kemudian pengujian yang dilakukan menggunakan teknik blackbox testing di mana pada pengujiannya hanya melihat fungsionalitas sistem terfokus bagian voice command untuk mengetahui apakah sudah berjalan dengan semestinya yaitu pemanggilan perintah membuka atau putar surah dan ayat tertentu[10].

\subsection{Analisa Masalah}

Berdasarkan latar belakang permasalahan sebelumnya, aplikasi Al Qur'an ini dibangun menggunakan sistem operasi android. Untuk menjawab kemajuan teknologi dan perkembangannya, maka pada aplikasi akan ditambahkan beberapa fitur unggulan yang salah satunya adalah michrophone untuk memberikan perintah voice command dengan teknologi speech recognition. Perintah untuk membuka surah dan ayat tertentu menjadi lebih efisien dan efektif menggunakan pemanggilan berbahasa Indonesia. 
Prinsip kerja speech to text yaitu memungkinkan suatu perangkat bisa mengenali dan memahami kata-kata yang diucapkan dengan cara digitalisasi kata tersebut dan pencocokan sinyal digital berupa gelombang suara yang memiliki pola tertentu yang tersimpan dalam perangkat. Gelombang suara itu akan menjadi sekumpulan angka yang kemudian disesuaikan dengan kode-kode tertentu untuk mengidentifikasi kata-kata tersebut[11].

Pemanfaatan teknologi pengenalan suara ini, dinilai memberikan kemudahan apalagi dapat diakses secara offline untuk memudahkan membuka atau memutar surah dan ayat[12]. Aplikasi ini dibangun dengan API library yaitu google speech API sebagai engine untuk mengenali kata yang diucapkan oleh pengguna.

Secara ringkas aplikasi yang dikembangkan akan menangkap suara yang dianggap sebagai perintah yaitu kata buka, putar, surah dan ayat tertentu sesuai keinginan pengguna. Kemudian aplikasi mengenali suara tersebut dengan teknologi speeh recognition secara online (tergantung smarthphone-nya). Suara yang telah dikenali sistem dikonversi ke dalam teks indonesian letter. Setelah pencarian berhasil akan tampil surah dan ayat yang dituju bahkan audio bisa langsung terputar.

\subsection{Analisa Data}

Tahap ini menganalisis data input berupa file berformat json yang berisi data Al Qur'an dengan terjemahan dan tafsir yang diunduh untuk ditanam ke dalam database lokal pada aplikasi. Dalam hal ini setelah dilakukan penelitian dipilihlah dari github atas perbandingan dengan beberapa sumber lainnya[13]. Audio per ayat diambil dari website alquran.cloud yang diunduh untuk dimasukkan ke server. Pelantun Al Qur'an dibuat streaming yang diambil dari website mp3quran.net dan video pembelajaran tahsin dari channel youtube rumah tajwid.

\subsection{Analisa Kebutuhan Sistem}

\subsubsection{Kebutuhan Fungsional}

Adapun kebutuhan fungsional yang disediakan aplikasi Al Qur'an ini dapat dilihat pada Tabel 1 berikut:

Tabel 1. Tabel Analisa Kebutuhan Aplikasi

\begin{tabular}{lll}
\hline No & Fitur & Deskripsi \\
\hline 1 & $\begin{array}{l}\text { Michroph } \\
\text { one }\end{array}$ & $\begin{array}{l}\text { Merupakan fitur utama dalam aplikasi yaitu } \\
\text { untuk pemanggilan surah atau ayat dengan } \\
\text { voice command. }\end{array}$ \\
2 & Surah & $\begin{array}{l}\text { Fitur yang memberikan daftar surah pada Al- } \\
\text { Qur'an. } \\
\text { Dan terdapat terjemahan pada aplikasi. }\end{array}$ \\
& Fitur yang memberikan daftar juz pada \\
3 & Juz & $\begin{array}{l}\text { Fiturasi yang ada pada bagian Al Qur'an bisa } \\
\text { dibuka manual pada setiap ayat } \\
\text { Akan otomatis ikut terputar ketika } \\
\text { pemanggilan ayat dan surah lewat voice } \\
\text { command. Dapat juga diputar manual pada } \\
\text { fitur Al Qur'an }\end{array}$ \\
& Audio &
\end{tabular}

\begin{tabular}{|c|c|}
\hline Qori' & $\begin{array}{l}\text { Merubah atau memilih qori untuk } \\
\text { melantunkan ayat }\end{array}$ \\
\hline Murrotal & $\begin{array}{l}\text { Fitur untuk memutar bacaan Al Qur'an } \\
\text { dengan playlist oleh pengguna pada aplikasi. }\end{array}$ \\
\hline Tahsin & $\begin{array}{l}\text { Fitur untuk pembelajaran berupa lima perkara } \\
\text { yang harus diperhatikan dalam membaca Al- } \\
\text { Qur'an. }\end{array}$ \\
\hline Akun & $\begin{array}{l}\text { Berisi bio masing-masing pengguna dan agar } \\
\text { setiap pengguna }\end{array}$ \\
\hline
\end{tabular}

Terdapat lima jendela utama pada Aplikasi yaitu fitur Al

Qur'an, murrotal, michrophone, akun dan home.

\subsubsection{Kebutuhan Non Fungsional}

Kebutuhan non fungsional meliputi hardware dan software yang digunakan dalam pembuatan aplikasi dapat yang dapat dilihat uraiannya pada Tabel 2 .

\begin{tabular}{|c|c|c|}
\hline No & Perangkat Keras & Software \\
\hline 1 & $\begin{array}{l}\text { Smartphone Android } \\
\text { versi 4.4.2 (1 unit) }\end{array}$ & Server \\
\hline 2 & Laptop (1 unit) & $\begin{array}{l}\text { Android Studio } \\
\text { versi 3.0.1/newest }\end{array}$ \\
\hline 3 & RAM 8 GB & $\begin{array}{l}\text { Java Development } \\
\text { Kit (JDK) versi } \\
6 / 7 / \text { newest }\end{array}$ \\
\hline 4 & Hardisk 500 GB & Star UML \\
\hline 5 & Processor Intel Core i3 & PowerPoint 365 \\
\hline 6 & - & $\begin{array}{l}\text { Google API (Voice } \\
\text { Recognaton) }\end{array}$ \\
\hline $\begin{array}{l}7 \\
8\end{array}$ & - & $\begin{array}{l}\text { Ionic versi } 5.0 \\
\text { MongoDB }\end{array}$ \\
\hline
\end{tabular}

Untuk versi android sendiri minimal versi 4.3 (Jelly Bean) untuk penggunaan voice recognation Google API. Penggunaan ionic yang merupakan framework SDK open source untuk membangun aplikasi mobile yang berkualitas tinggi karena memanfaatkan AngularJS sebagai implementasi logikanya menjadi lebih cepat[14]. Dimana semua kode pemrograman aplikasi dibuat dari ionic yang kemudian dicompile lagi ke android studio untuk menjadi aplikasi berbasis android.

\subsection{Perancangan Database}

Banyak pilihan untuk media penyimpanan yang dapat digunakan untuk menyimpan data. MongoDB adalah sebuah sistem database yang berbasis dokumen (Document Oriented Database) dan NoSQL. Not Only $S Q L$ yang artinya sebuah sistem database tidak harus menggunakan $S Q L$ untuk memanipulasi data. Tidak memiliki tabel, kolom, dan baris. Hanya memiliki atribut dan dokumen[16]. MongoDB digunakan karena lebih fleksibel dalam aplikasi ini untuk penyimpanan data pengguna berupa CRUD (Create, Read, Updated, Delete) dan proses regsitrasi dan login pada aplikasi.

Tabel 3 adalah atribut akun dari dokumen quran_users pada MongoDB.

\begin{tabular}{lll}
\multicolumn{2}{c}{ Tabel 3. Tabel Atribut } & Akun MongoDB \\
\hline No & Atribut Akun & Isi Atribut \\
\hline 1 & namaLengkap & Nama Lengkap \\
2 & email & Email \\
3 & tglLahir & Tanggal Lahir
\end{tabular}

DOI: https://doi.org/10.29207/resti.v5i5.3541

Lisensi: Creative Commons Attribution 4.0 International (CC BY 4.0) 


\begin{tabular}{lll}
4 & jenisKelamin & Jenis Kelamin \\
5 & noTlp & $\begin{array}{l}\text { No.Telp } \\
\text { (Whatsapp) }\end{array}$ \\
& & Alamat \\
6 & alamat & Password \\
7 & password & \\
\hline
\end{tabular}

Sedangkan di dalam aplikasi sendiri terdapat SQLite yang merupakan database yang tertanam di dalamnya (lokal). Terdapat 6 tabel yang dirancang untuk database aplikasi Al Qur'an ini diantaranya :

\section{a. Tabel Surat}

Tabel 4 ini merupakan entitas yang mencakup data umum Al Qur'an, atribut "urutan" merupakan primary key dari tabel ini.

\begin{tabular}{lll}
\multicolumn{3}{l}{ Tabel } \\
\hline No & Nabel Rancangan Database: Surat \\
\hline 1 & urutan & Type \\
2 & nama & Int(11) \\
3 & alias & Varchar \\
4 & ayat & Varchar \\
5 & jumlahAyat & int [11] \\
6 & turun & Varchar \\
7 & arab & Text \\
8 & order & int [11] \\
9 & playlist & Boolean \\
10 & nilai & Float \\
\hline
\end{tabular}

\section{b. Tabel Bookmark}

Tabel 5 merupakan entitas menseting bacaan terakhir untuk Al Qur'an.

\begin{tabular}{|c|c|c|}
\hline No & Nama Field & Type \\
\hline 1 & urutan & $\operatorname{Int}(11)$ \\
\hline 2 & ayat & Int (11) \\
\hline 3 & open & Boolean \\
\hline
\end{tabular}

\section{c. Tabel Qori}

Tabel 6 merupakan entitas yang mencakup pilihan qori yang harus lebih dulu diatur jika ingin memuta murrotal.

\begin{tabular}{lll}
\multicolumn{2}{c}{ Tabel } & 6.Tabel Rancangan Database: Qori \\
\hline No & Nama Field & Type \\
\hline 1 & id & Int(11) \\
2 & nama & Varchar \\
3 & foto & Blob \\
4 & baseLink & Varchar \\
\hline
\end{tabular}

\section{d. Tabel PlayerMurrotal}

Tabel 7 merupakan entitas yang mencakup proses memainkan audio murrotal.

\begin{tabular}{cll} 
Tabel 7. Tabel Rancangan Database: PlayerMurrotal \\
\cline { 2 - 3 } No & Nama Field & Type \\
\hline 1 & loaded & Boolean \\
2 & played & Boolean \\
3 & repeat & Boolean \\
4 & muted & Boolean \\
5 & duration & Varchar \\
6 & currentTime & Int (11) \\
7 & playIndex & Int (11) \\
8 & playlistLength & Int (11) \\
\hline
\end{tabular}

\section{e. Tabel PlayQuran}

Tabel 8 merupakan entitas yang mencakup bagian playlist pada fitur murrotal.

\begin{tabular}{lll} 
Tabel & 8.Tabel Rancangan Database : PlayQuran \\
\hline No & Nama Field & Type \\
\hline 1 & surat & Varchar \\
2 & ayat & Int [11] \\
3 & urutan & Int [11] \\
4 & jAyat & Int [11] \\
\hline
\end{tabular}

\section{f. Tabel Tahsin}

Tabel 9 merupakan entitas yang mencakup bagian home terdapat tahsin dan menu-menu lainnya.

\begin{tabular}{lll}
\multicolumn{2}{l}{ Tabel } & 9. Tabel Rancangan Database : Tahsin \\
\hline No & Nama Field & Type \\
\hline 1 & _id & int [11] \\
2 & nama & Varchar \\
3 & keterangan & Varchar \\
4 & coomingsoon & Boolean \\
5 & arab & Text \\
6 & keterangan & Text \\
7 & link & Varchar \\
\hline
\end{tabular}

\subsection{Perancangan Sistem}

Tahap ini merupakan lanjutan dari analisa kebutuhan sistem di mana digambarkan rancangan sistem yang akan dibangun sebelum implementasi berupa pengkodean kedalam bahasa pemrograman. Aplikasi ini menyediakan Al Qur'an 30 juz dilengkapi terjemahan dan tafsir. Selain itu, terdapat fitur lain sebagiman pada Tabel 1 sebelumnya.

\subsubsection{Perancangan UML}

\section{a. Flowchart/Arsitektur Cara Kerja Sistem}

Aplikasi ini dibangun menggunakan bantuan voice recognition dari Google API. Dengan request perintah berkaitan dengan nama surah dan ayat.

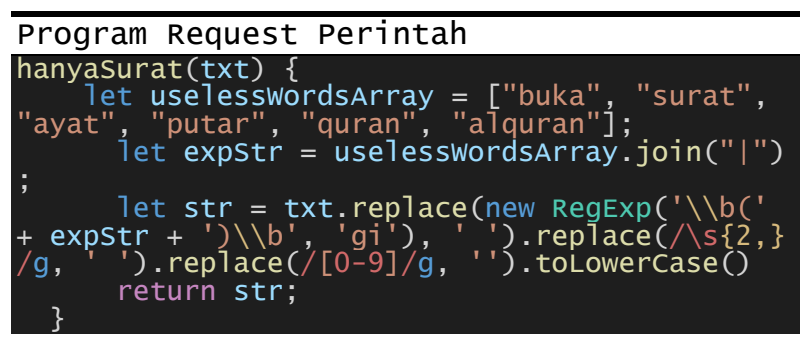

Gambar 1 adalah diagram atau alur kerja sistem yang perlu diperhatikan dalam pembuatan aplikasi dan penjelasannya.

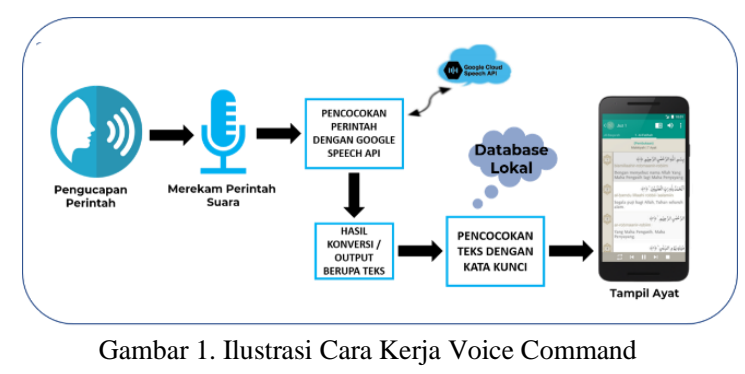

DOI: https://doi.org/10.29207/resti.v5i5.3541

Lisensi: Creative Commons Attribution 4.0 International (CC BY 4.0) 
Seluruh proses yang terdapat pada aplikasi Al Quran ini 2.5.2. Perancangan Interface

diterapkan untuk smartphone berbasis android. Cara kerja aplikasi asisten Al Quran adalah dengan menggunakan michrophone, dimana pengguna mengeklik michrophone kemudian akan muncul kolom speech to text, lalu diucapkan putar nama surah dan ayat yang selanjutnya akan dicocokkan oleh server google API, suara berubah menjadi teks yang dibawa lagi untuk dilihat kemiripannya dalam database lokal pada aplikasi bukan berdasarkan primary key. Dan hasilnya akan tampil surah dan ayat yang diminta serta audio diputar secara otomatis.

Flowchart sistem sendiri adalah bagian yang menujukkan alur kerja sistem secara umum dan keseluruhan yang menjelaskan prosedur-prosedur yang terjadi, seperti pada gambar 2 .

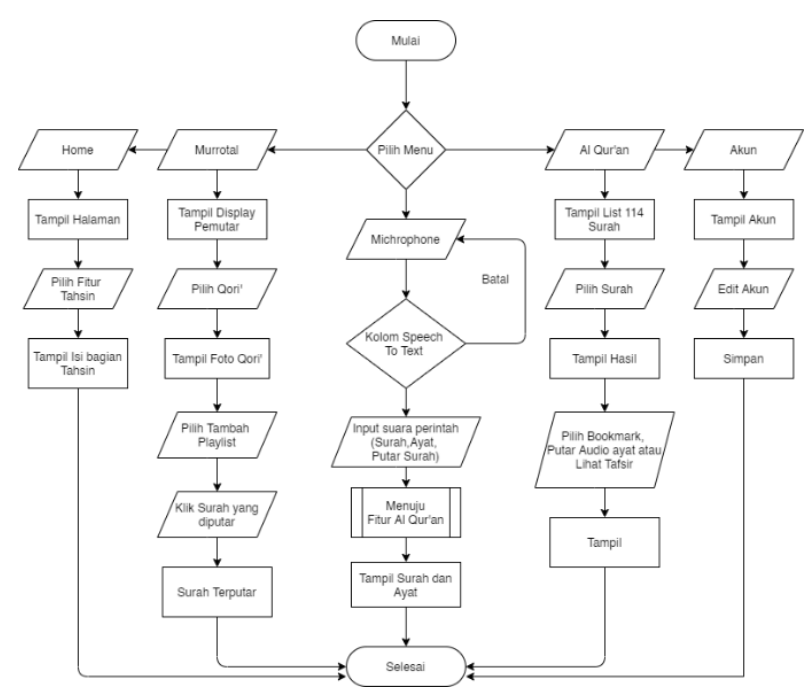

Gambar 2. Usecase Diagram Aplikasi

b. Usecase Diagram

Menggambarkan interaksi pengguna aplikasi dengan sistemnya. Dengan usecase dapat diketahui siapa yang berinteraksi dengan sistem dan apa saja yang dapat dilakukan oleh sistem[15]. Gambar 3 merupakan usecase umum dari rancangan sistem aplikasi ini.

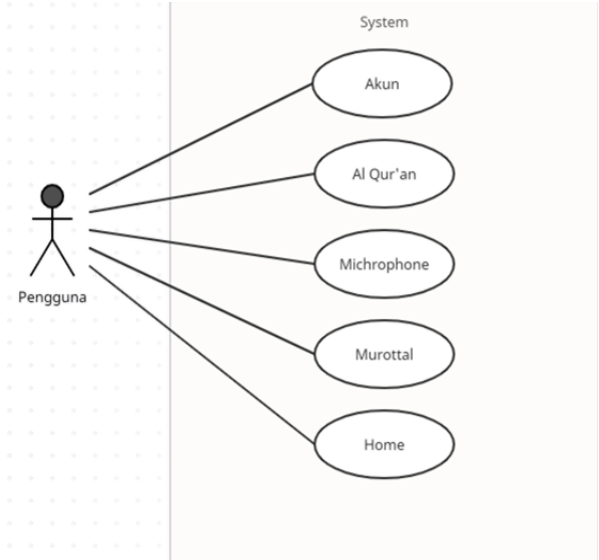

Gambar 3. Usecase Diagram Pengguna

DOI: https://doi.org/10.29207/resti.v5i5.3541 bagiannya.
Berikut ini adalah beberapa rancangan interface yang memudahkan dalam implementasi aplikasi. Dimana pada gambar 4 terdapat fitur home dengan setiap

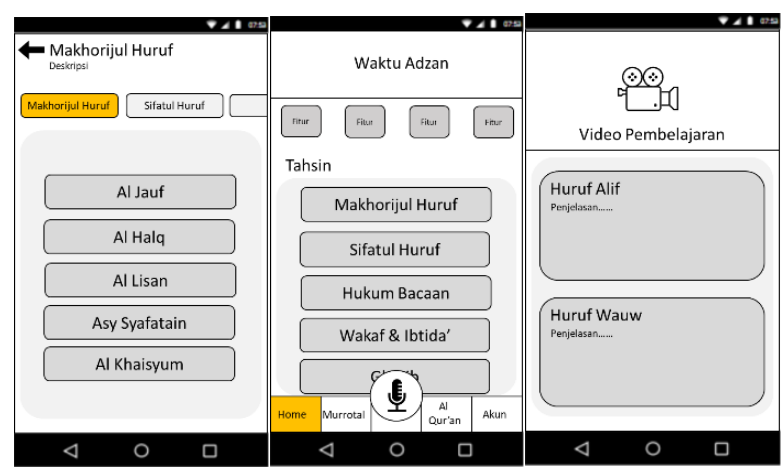

Gambar 4. Fitur Home dan bagian Tahsin

Gambar 5 adalah fitur murrotal dan beberapa bagiannya berupa cara menentukan playlist.

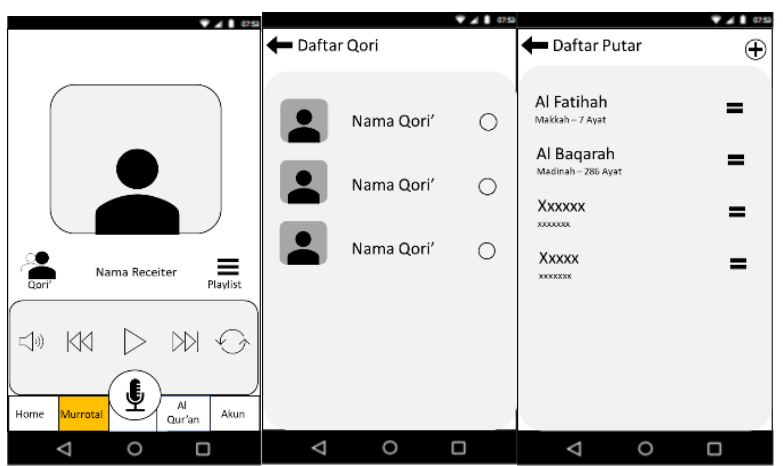

Gambar 5. Fitur Murrotal dan bagian pilih playlist

Gambar 6 yaitu fitur Al Qur'an dan beberapa bagiannya seperti cara memilih tafsir, putar audio ayat dan bookmark.

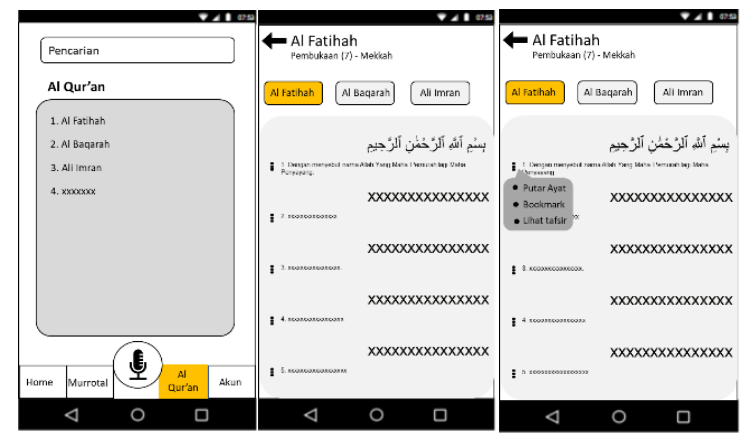

Gambar 6. Fitur Al Qur'an dan bagian audio perayat, bookmark serta tafsir

Gambar 7 merupakan fitur akun untuk pengguna mengisikan data masing-masing. 


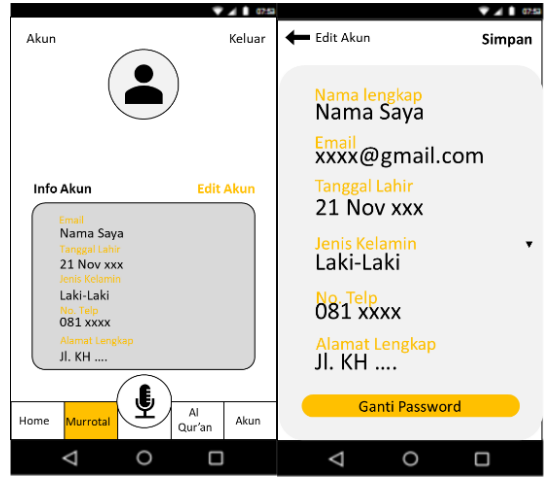

Gambar 7. Fitur akun bagian edit akun dan ganti password

\section{Hasil dan Pembahasan}

Berikut merupakan tahapan hasil yang akan membahas tentang aplikasi siap pakai yang telah dibangun. Tampilan utama pada aplikasi ini yaitu tampilan home yang mana menyajikan pengguna pada fitur umum seperti waktu sholat, murrotal, Al Qur'an, pembelajaran tahsin serta akun dan tombol microphone untuk memasukkan perintah. Selain itu terdapat fitur mendatang seperti kalender hijriyah dan arah kiblat. Dari kesemua fitur ini membawa manfaat besar bagi pengguna karena memiliki fitur yang sangat lengkap. Gambar 8 merupakan tampilan home pada aplikasi.

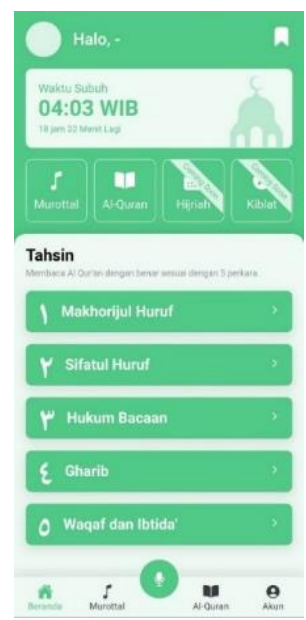

Gambar 8. Interface Halaman Home

Gambar 9 merupakan tampilan dari voice command apabila microphone dipilih. Ketika microphone dipilih, dari aplikasi akan menyala suara "ada yang bisa kamu bantu?" kemudian tampil gambar microphone yang menandakan bahwa aplikasi siap menerima perintah berupa suara. Jika perintah tidak dapat dideteksi, maka microphone akan menampilkan button untuk menerima kembali perintah dari pengguna.

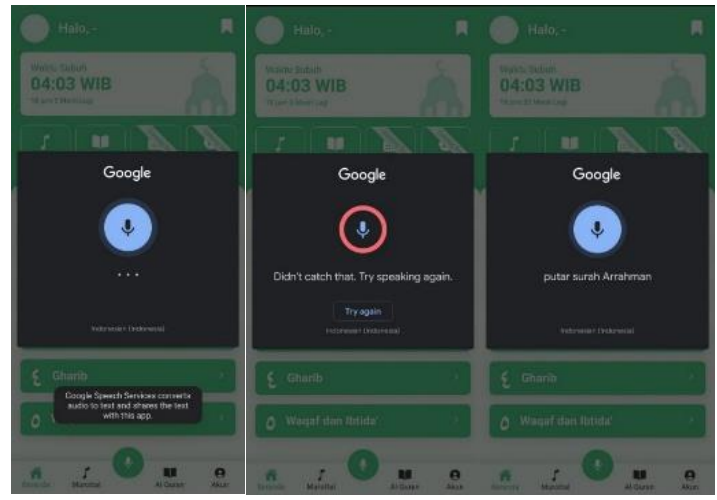

Gambar 9. Interface Microphone

Pada voice command yang dapat diterima pada microphone ini diantaranya yaitu yang memiliki kata kunci putar untuk memutar murottal pada suatu surah atau ayat tertentu serta kata buka untuk membuka surah atau ayat tertentu. Setelah perintah diterima, aplikasi akan segera menuju ke surah atau ayat yang diminta oleh pengguna. Gambar 10 merupakan tampilan dari hasil perintah putar surah Ar Rahman yang memutarkan audio secara otomatis.

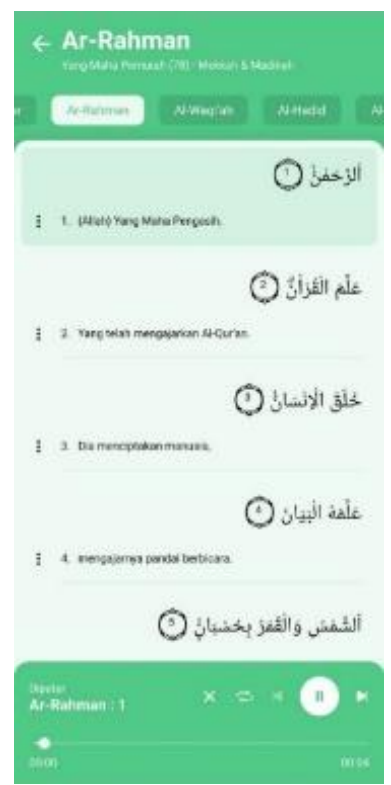

Gambar 10. Tampilan pemanggilan dari Surah Ar-Rahman

Sedangkan pada gambar 11 terdapat fitur murrotal, pengguna bisa memilih playlist dan menukar posisinya serta terdapat qori' pilihan untuk membacakan murrotal nantinya.

DOI: https://doi.org/10.29207/resti.v5i5.3541 


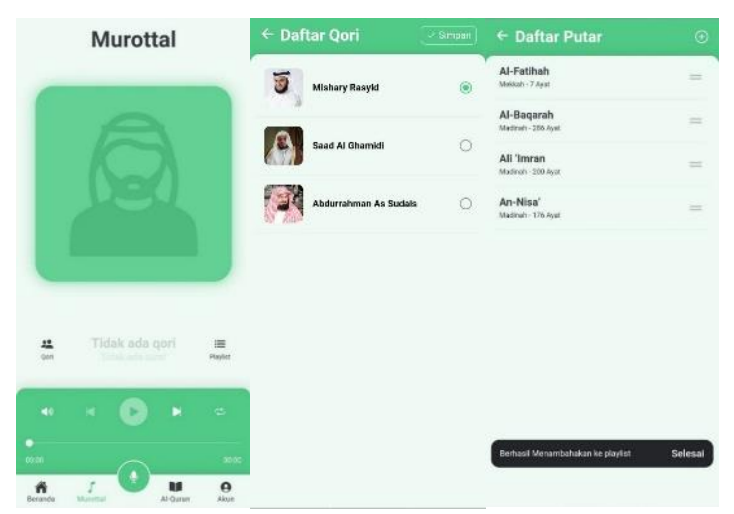

Gambar 11. Tampilan Interface Murrotal serta Penambahan Playlist dan Pilihan Qori'

Adapun membuka Al Qur'an secara manual terdapat fitur tersendiri yang menampilkan lengkap sebanyak 30 juz yaitu 114 surah beserta artinya. Selain itu, terdapat tafsir pada setiap ayatnya baik berupa sejarah turunnya ayat, tafsir dari penafsir masyhur, dasar dari sebuah hukum syari'at dan lain sebagainya yang dikeluarkan KEMENAG. Fitur lainnya, pengguna dapat mencari surat atau tafsir yang dimaksud pada kolom search yang tersedia sehingga pengguna tidak perlu scroll atau mencari satu-persatu untuk mencari ayat atau tafsir tertentu. Gambar 12 adalah tampilan untuk membuka tafsir atau memutar manual audio ayat.

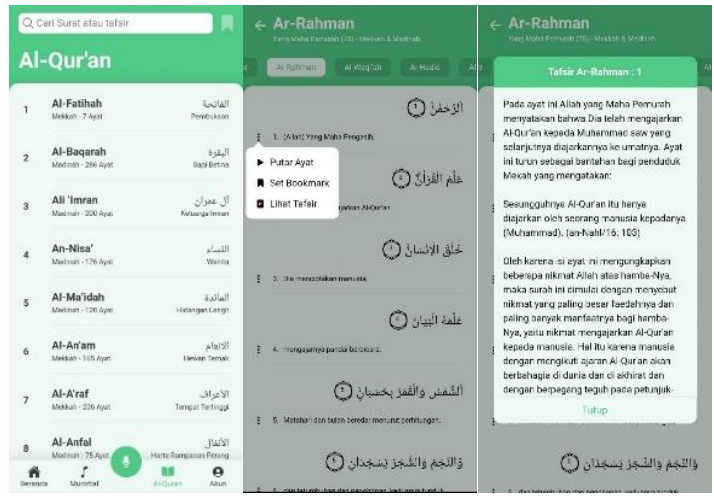

Gambar 12. Tampilan Interface Al Qur'an dan Tafsirnya

Dalam pengujian akurasi voice command pada aplikasi ini, penulis melakukan pengujian sebanyak 10 kali memberikan perintah mulai dari perintah buka, putar atau hanya menyebutkan surah secara acak. Jika perintah diawali kata putar maka akan memutar ayat secara otomatis selain membukanya. Sedangkan perintah selain Kepada pihak DIKTI KEMENDIKBUD yang telah diawali kata putar hanya kan membuka surah dan ayat mendanai, dan pihak Univeritas Muhammadiyah yang diinginkan. Dari hasil percobaan tersebut Malang yang telah membantu dalam pengajuan HKI persentase keberhasilan deteksi dapat dihitung berupa Hak Cipta. menggunakan persamaan berikut [17].

$$
\% \text { Berhasil }=\frac{\text { Jumlah deteksi benar }}{\text { Jumlah } U j i} \times 100 \%
$$

Tabel 10.Tabel Pengujian Voice Command

\begin{tabular}{lll}
\hline No & Pengujian Voice Command & Hasil \\
\hline 1 & Buka Al Baqarah ayat 200 & Sukses \\
2 & Al Waqi'ah ayat 5 & Sukses
\end{tabular}

\section{Daftar Rujukan}

[1] A. Fauzan, I. Arwani, and L. Fanani, "Pembangunan Aplikasi Iqro' Berbasis Android Menggunakan Google Speech," $J$. Pengemb. Teknol. Inf. dan Ilmu Komput., vol. 2, no. 1, pp. 2935, 2018.

[2] H. Nufus, N. Solekhah, M. Sarosa, and M. Zakaria, "Rancang Bangun Aplikasi Al Quran Digital Untuk Penyandang

DOI: https://doi.org/10.29207/resti.v5i5.3541

Lisensi: Creative Commons Attribution 4.0 International (CC BY 4.0) 
Disabilitas Tangan Berbasis Command Voice Pada Perangkat," Proceeding SENDI_U, pp. 978-979, 2015, [Online]. Available: http://www.unisbank.ac.id/ojs/index.php/sendi_u/article/downl oad/3359/965.

[3] M. I. Krisnaldi, U. Wafiat, and F. Habibie, "Juz Amma Zaman Now . Aplikasi Penghafal Juz Amma ( Tahfidz Qur' an ) Berbasis Android Juz Amma Zaman Now . Application for memorizing Juz Amma ( Tahfidz Qur' an ) Android-based," $e$ Proceeding Appl. Sci., vol. 4, no. 2, pp. 675-684, 2018.

[4] R. Pratama, "Rancang Bangun Aplikasi Pemutar Lantunan Alquran Menggunakan Google Speech API," J. SITECH Sist. Inf. dan Teknol., vol. 1, no. 2, pp. 133-138, 2019, doi: 10.24176/sitech.v1i2.2399.

[5] K. Nugroho, "Javanese Gender Speech Recognition Based on Machine Learning Using Random Forest and Neural Network," Sisforma, vol. 6, no. 2, p. 50, 2020, doi: 10.24167/sisforma.v6i2.2402.

[6] K. Khairunizam, D. Danuri, and J. Jaroji, "Aplikasi Pemutar Musik Menggunakan Speech Recognition," INOVTEK Polbeng - Seri Inform., vol. 2, no. 2, p. 97, 2017, doi: 10.35314/isi.v2i2.196.

[7] F. Islami, G. I. Marthasari, and E. B. Cahyono, "Prototype Aplikasi Pencarian Informasi Ayat Al-Quran Berdasarkan Suara Bacaannya Berbasis Android," J. Repos., vol. 2, no. 5, p. 561, 2020, doi: 10.22219/repositor.v2i5.564.

[8] G. Wiro Sasmito, "Penerapan metode Waterfall pada desain sistem informasi geografis industri kabupaten Tegal," J. Inform. Pengemb. IT, vol. 2, no. 1, pp. 6-12, 2017.

[9] Y. Syafitri, "Analisa dan Perancangan Berbasis UML pada Sistem Informasi Simpan Pinjam Koperasi Swamitra Bandar Lampung," J. Mater. Process. Technol., vol. 1, no. 1, pp. 1-8, 2018, [Online]. Available: http://dx.doi.org/10.1016/j.cirp.2016.06.001\%0Ahttp://dx.doi. org/10.1016/j.powtec.2016.12.055\%0Ahttps://doi.org/10.1016/ j.ijfatigue.2019.02.006\%0Ahttps://doi.org/10.1016/j.matlet.20 19.04.024\%0Ahttps://doi.org/10.1016/j.matlet.2019.127252\%
0Ahttp://dx.doi.o.

[10] T. S. Jaya, "Pengujian Aplikasi dengan Metode Blackbox Testing Boundary Value Analysis," J. Inform. J. Pengemb. IT, vol. 03, no. 02, pp. 45-48, 2018, doi: 10.30591/jpit.v3i1.647.

[11] X. Lu, S. Li, and M. Fujimoto, "Automatic speech recognition," SpringerBriefs Comput. Sci., pp. 21-38, 2020, doi: 10.1007/978-981-15-0595-9_2.

[12] A. G. S. S. M.SI., "APLIKASI SPEECH RECOGNITION BAHASA INDONESIA BERBASIS ANDROID.” 2018, p. [Online], [Online]. Available: https://socs.binus.ac.id/2018/12/20/aplikasi-speechrecognition-bahasa-indonesia-berbasis-android/.

[13] Rio Astamal, "GitHub - rioastamal_quran-json_ Holy Quran with translation and tafsir in Bahasa Indonesia, presented in JSON format." 2021, [Online]. Available: https://github.com/rioastamal/quran-json.

[14] M. Suhaidi, N. Nurhadi, and L. Latip, "Penerapan Framework Ionic Dalam Perancangan Aplikasi E-Concept Sebagai Alat Terukur Dalam Perekrutan Simpatisan Pemilukada," Sebatik, vol. 24, no. 2, pp. 253-258, 2020, doi: 10.46984/sebatik.v24i2.1135.

[15] A. R. Pratama, "Belajar Unified Modeling Language (UML) Pengenalan," Https://Www.Codepolitan.Com/, no. October 1995. p. 1, 2019, [Online]. Available: https://www.codepolitan.com/unified-modeling-language-uml.

[16] E. K. Putra and F. Rahmayeni, "Implementasi Database MongoDB Untuk Sistem Informasi Bimbingan Konseling Berbasis Web (Studi Kasus: SMPN 1 Sawahlunto)," J. TeknoIf, vol. 4, no. 1, pp. 67-73, 2016, [Online]. Available: https://ejournal.itp.ac.id/index.php/tinformatika/article/viewFil e/591/427.

[17] L. S. Ramba, "Design Of A Voice Controlled Home Automation System Using Deep Learning Convolutional Neural Network (DL-CNN)," Telekontran J. Ilm. Telekomun. Kendali dan Elektron. Terap., vol. 8, no. 1, pp. 57-73, 2020, doi: 10.34010/telekontran.v8i1.3078.

DOI: https://doi.org/10.29207/resti.v5i5.3541 